\title{
Economics of Groundnut Production among Smallholder Farmers in Michika Local Government Area of Adamawa State, Nigeria
}

\author{
Lawal Haruna, Muhammad Auwal Ahmed
}

Department of Agricultural Economics and Extension, Modibbo Adama University of Technology, P.M.B. 2076 Yola Adamawa State, Nigeria

\begin{abstract}
This study assessed economics of groundnut production among smallholder farmers in Michika local government area of Adamawa State, Nigeria. Multistage sampling technique which involves purposive selection of Michika and simple random selection of farmers from eight wards was embraced in collecting primary data from 172 farmers using structured questionnaire. The analytical tools used were mainly descriptive, gross margin and regression analysis. The analysis found that groundnut production is profitable with an average gross margin of \$97,477.80, total revenue of $\$ 167,160$, and net farm income of 94,540.64 per hectare. The regression analysis indicated that Cobb-Douglas production function gave the best fit with $R^{2}$ value of 0.748 , implying that the specified factor inputs in the regression equation explained up to $74.8 \%$ of the variation in groundnut output and only $25.2 \%$ was accounted for by the random error term. Production inputs such as farm size, labour, agrochemicals, seeds and farming experience were statistically significant at varying levels of probability. This means that any increase in such inputs would bring about increase in groundnut output. Resource use efficiency analyses indicate that the ratios of $M V P$ and MFC in respect to seeds, labour and Agrochemicals were greater than unity and hence were under-utilized by the farmers during production period. Therefore, policies aimed at assigning more production inputs to farmers should be introduce by government in order to enhance farmers' output and profitability.
\end{abstract}

Keywords-Profitability, Resource use efficiency, Regression, Groundnut, Smallholders.

\section{INTRODUCTION}

Groundnut (Arachishypogaea L.) is a leguminous oilseed crop which contains $20-50 \%$ protein, $40-50 \%$ fat and 10 $20 \%$ carbohydrate. It is cultivated in the semi-arid and subtropical regions of about 114 countries of the world on nearly 31.2 million hectares, with a total output of 60.5 million metric tons (mmt)at an average productivity of 1.4 metric tons per haduring2014[International Crop Research Institute for the Semi-Arid Tropics,[1,2]. Malaysia, Israel, China, Nicaragua, Nigeria, USA and Saudi Arabia are some of the leading groundnut producing countries in the world. Asia, with $25.6 \mathrm{mmt}$ (58.28\%) and Africa, with $13.9 \mathrm{mmt}$ (31.62\%) grasps maximum global groundnut output. Developing countries in Asia, Africa and South America account for $99.85 \%$ of the total quantity of groundnut produced in the world in 2014 [2]. Groundnut is an important crop in many developing countries where it serves as a protein source, vitamins and cooking oil. Groundnut is the $13^{\text {th }}$ most significant food crop of the world. It is the world's $4^{\text {th }}$ most vital source of edible oil and $3^{\text {rd }}$ most important source of vegetable protein[3]. The haulms being a good source of feed supplement for livestock, also increases farmers income particularly during the dry season when fresh green grasses are in short supply and the silage is in high demand[1].

The meager output of groundnut in African countries may be attributed to production challenges such as rainfall variability and drought, poor soil fertility, biotic and abiotic constraints, input supply constraints, traditional smallholder farming with little or no mechanization, prevalence of pests and diseases and partial extension services. Groundnut is a major source of edible oil as well as employment generation for smallholder farmers in Northern Nigeria where $48 \%$ of the total output in West Africa was produced in 2015.It occupies about $34 \%$ of the total land area under cultivation and contributes $23 \%$ of household earnings of the country. The total output was $1.6 \mathrm{mmt}$ in 1961 , but fell to $4.5 \mathrm{mmt}$ in 1982.Since 1996, production has been increasing at an estimated rate of $2.3 \mathrm{mmt}$ to about $3.4 \mathrm{mmt}$ in 2015[2], as a result of both area expansion (5.52\%) and increase in productivity [4].

Previous studies on groundnut production of smallholder farmers provide a variety of results. [5], in a study on the 
profit and market efficiency of modern groundnut oil extraction of RMP-12 and Ex-dakar varieties discovered that it was a profitable venture, though with a low profit margin. [6]In a study entitled economics of groundnut production in Nigeria indicated that groundnut is a profitable enterprise as farmers received a net farm income of $\$ 14,355$ per hectare. A similar view was shared by [7], who indicated that the total revenue, gross margin and net farm income per hectare were $\$ 100,818, \$ 42,422$ and \#1, 172 respectively whereas the gross margin and net farm income per naira invested were $\$ 0.73$ and $\$ 0.69$ respectively, implying that groundnut production in Northern Part of Taraba State was profitable.

[8], observed that groundnut production in Adamawa State, Nigeria is profitable as farmers realized a total revenue of \$90, 843.75, gross margin of $\$ 31,363.75$ and net farm income of $\$ 29,003.75$ per hectare. In order to maximize profit, farmers should procure their required inputs from a competitive market and should make use of the obtainable organic manure to minimize cost of production where necessary. According to [9], pests and diseases, inadequate inputs, instability of market prices, high cost of inputs and poor storage facilities negatively affect the efficiency and marketing of groundnut product. Others as indicated by [10], include transportation cost, proximity to market location, infrastructural facilities like road network and exploitative activities of middle men that are involve in buying and selling affect profitability of groundnut production in Nigeria.

Inspite the enormous importance of this cash crop, availability of ample land and human resources in Nigeria, there seems to be inadequate supply of groundnut product to meet both local and international market demand. Therefore, there is need to explore the economics of groundnut production among smallholder farmers in Adamawa State, Nigeria. The study evaluates the costs and returns associated with groundnut production in Michika Local Government Area, determined the relationship between inputs and output as well as the resource use efficiency of groundnut production in the area.

\section{METHODOLOGY}

\subsection{Study area}

The research was conducted in Michika local government area (LGA) of Adamawa State. It is situated at the far north east of the state which lies between latitude $11^{0}-8^{\prime}$ South and longitude $15^{0}-13^{\prime}$ E. It is bounded to the North by MadagaliLGA and shares an international boundary with the Republic of Cameroun in the North-East. It is bounded on the West by Borno State and by Mubi and Hong LGAsin the South. The LGA has four development areas namely Michika metropolitan, Garta, Bazza and Madzi which covers a land mass of $961 \mathrm{~km}^{2}$ with an estimated population of 211,124[11]. The study area is heterogeneous in ethnic composition. It is agrarian in nature and has a great percentage of its populace engaged in farming as an occupation. It has a tropical type of climate marked by distinct dry and rainy seasons. The dry season commences in December and ends in April whereas the wettest months are August and September (Adebayo, 1999).

\subsection{Data Collection}

Multistage and simple random sampling techniques were used to gather information from the farmers. In the first stage, Michika LGA was selected based on it prominence in groundnut production. The second stage involved the selection of eight wards from a total of sixteen wards that made up the study area. This is followed by the selection of two villages each from the selected wards given rise to sixteen villages all together. Finally, a sample of 186 groundnut farmers were randomly selected from a sampling frame of 360 registered farmers in the study area. Though, only 172 questionnaires were retrieved and use for the analysis due to inappropriate response from the respondents. Data collected was based on production inputs, outputs, both inputs and output prices as well as sociodemographic characteristics of the farmers for the year 2017 cropping season.

\subsection{Data analysis}

This involved both descriptive and inferential analysis. Inferential analyses such as gross margin technique and regression model as used by [7], [9],[5] and[6]were adopted for the study.

\subsection{Model specification}

\subsubsection{Gross margin}

Gross margin technique was used to determine the profitability (costs and returns) of groundnut production in the study area. The model is specified as follows:

$$
\begin{aligned}
& G M=T R-T V C \\
& N F I=G I-T C \\
& T C=T V C+T F C \\
& R N I=\frac{N F I}{T C}
\end{aligned}
$$

Where;

$$
G M=\text { Gross Margin }
$$


$T R=$ Total Revenue

$T V C=$ Total Variable Cost

$T F C=$ Total Fixed Cost

$N F I=$ Net Farm Income

$G I=$ Gross Income realized from groundnut production

$T C=$ Total Cost of groundnut production

$R N I=$ Return on every naira invested during the production process

\subsubsection{Regression analysis}

Regression is defined as the amount of change in the value of one variable associated with a unit change in the values of the other variables. However, this study appliedfour different functional formssuch as linear, double-log, exponential and semi-log functions to determine the inputs (independent variables) and output (dependent variable) relationship. The specifications of the functions are given as:

( $i$ ) Linear function

$Y=b_{o}+b_{1} X_{1}+b_{2} X_{2}+b_{3} X_{3}+\ldots+b_{7} X_{7}+\mu_{i}$

(ii) Double-log function

$\ln Y=\ln b_{o}+b_{1} \ln X_{1}+b_{2} \ln X_{2}+b_{3} \ln X_{3}+\ldots+b_{7} \ln X_{7}$ (6)

(iii) Exponential function

$\ln Y=b_{o}+b_{1} X_{1}+b_{2} X_{2}+b_{3} X_{3}+\ldots+b_{7} X_{7}+\mu_{i}$

(iv) Semi-log function

$Y=\ln b_{o}+b_{1} \ln X_{1}+b_{2} \ln X_{2}+b_{3} \ln X_{3}+\ldots+b_{7} \ln X_{7}+\mu_{i}$ (8)

Where;

$Y=$ Quantity of groundnut shell produced measured in kilogram

$X_{1}=$ Years of farming experience

$X_{2}=$ Agrochemicals used measured in liters

$X_{3}=$ Fertilizer used measured in kilogram

$X_{4}=$ Man-days of labour

$X_{5}=$ Farm size measured in hectares

$X_{6}=$ Quantity of seeds measured in kilogram

$X_{7}=$ Access to extension services (Dummy: 1 if a farmer

had access to extension services, $0=$ otherwise)

$b_{1}-b_{7}=$ Estimated regression parameters $\mu_{i}=$ Error term

The apriori expectation was that the coefficients of $X_{1}-X_{7}$ would be positive.

\subsubsection{Resource use efficiency}

The estimated coefficients of the linear regression model wereused to compute the marginal value product (MVP) and it ratio (r), whilemarginal factor cost (MFC)was usedto determine the economic efficiency of resource used.The model was estimated as given below:

$r=\frac{M V P}{M F C}$

Where: $r$ represents the efficiency ratio, $\mathrm{MVP}=$ marginal value product of the variable inputs and $\mathrm{MFC}=$ marginal factor cost i.e. price per unit of input.

Based on economic theory as also reported by [13] and[14], a firm maximizes profits with respects to resource use when the ratio of the marginal return to the opportunity cost is one. However, the values are interpreted as:

(i) If $\mathrm{r}$ is less thanone, resource is over utilizehence reducing the quantity use of that resource willincrease farmers'profits.

$+(\not t)$ If $r$ is greater than one, resource is being underutilized during production hence increasing the quantity use of the resource will upsurge profitlevel accruing to the farmers.

(iii) If $\mathrm{r}$ is equal to one, it showsthe resource is being used efficiently and that is the point ofprofit maximization [15].

\footnotetext{
3.1 Economic analysis of groundnut production
}

Economics of groundnut production was analyzed using 2017 prevailing market prices of inputs and output as presented in Table 1. The average output obtained per hectare was $597 \mathrm{~kg}$, while the average selling price $/ \mathrm{kg}$ was N280. The total variable cost incurred on production constituted the greater proportion of the total production cost which was estimated at $\$ 69,682.20$ (95.96\%), while the total fixed cost which is depreciated on land and equipment was $\$ 2,937.16$ (4.04\%) implying that variable cost is the most sensitive components in groundnut production. The gross margin and total revenue received from the sale of groundnut output in the study area on average was $\$ 97,477.80$ and $\$ 167,160$ respectively. The results further revealed that net farm income was estimated at $\$ 94,540.64$, while the return per naira invested was $\$ 1.30$ per hectare. This indicated that for every naira invested in groundnut production in the study area, a farmer 
realized a profit of $\$ 1.30$. Therefore, groundnut production is a profitable venture inMichika local government area. The results agreed with the findings of [16], [8],[17], [7],
[9], who in their different studies reported that groundnut production is highly profitable.

Table.1: Average Cost and Returns in Groundnut Production/Hectare/Farmer

\begin{tabular}{|c|c|c|c|}
\hline Variables & & Amount in naira/ha & Percent \\
\hline Total Variable Cost (TVC) & & $69,682.20$ & 95.96 \\
\hline Total Fixed Cost (TFC) & & $2,937.16$ & 4.04 \\
\hline Total cost of production (TC) & & $72,619.36$ & 100.0 \\
\hline \multicolumn{4}{|l|}{ Returns } \\
\hline Total output & $247,755 \mathrm{~kg}$ & & \\
\hline Output/ha & $597 \mathrm{~kg}$ & & \\
\hline Total hectare of land & 415 & & \\
\hline Price/kg & & 280 & \\
\hline Total Revenue (TR) & & 167,160 & \\
\hline Gross Margin (TR-TVC) & & $97,477.80$ & \\
\hline Net Farm Income (GM-TFC) & & $94,540.64$ & \\
\hline RNI & & 1.30 & \\
\hline
\end{tabular}

Source: Field Survey, 2017

\subsection{Regression analysis result}

This section presents the results of four different functional forms which include Linear, Semi-logarithm (linear-log and log-linear) and Double-logarithm analyzed using Eviews 8 statistical package (Table 2). Based on the summary of the results, Double-logarithm function gave the best fit and was chosen as the lead equation. The selection of lead equation was based on the comparison of coefficients ofmultiple determinations $\left(\mathrm{R}^{2}\right)$, statistical significance of the F-ratios, the magnitude of standard error of the estimated parameters $\left(b_{1}-b_{7}\right)$,statistical significance of the estimated regression coefficients and the apriori expectation. Since Doublelogarithm function gave the best fit, the regression coefficients are still the elasticities. Elasticity of production is defined as the measure of output response to changes in the variable input [18]. The coefficients of all the explanatory variables bore positive signs and hence reflect the apriori expectation. The predictive power of the model represented by $\mathrm{R}^{2}$ was 0.748 , meaning the specified factor inputs explained up to $74.8 \%$ of the variation in groundnut output and that only $25.2 \%$ was taken care by the random error term. The overall significance (F-statistic) of the model at $1 \%$ explains the fitness of the model.

Farm size being one of the most important variables was found to be positive (0.298) and statistically significant at $1 \%$ level of probability. This means that a $1 \%$ increase in hectare of land under cultivation would increase output by $29.8 \%$. This also indicated that land as a factor of production is very important in groundnut production in the study area as farmers tend to derive the benefits of economies of scale. This result is in conformity with the findings of [7] and [6] who found out that farm size is one of the most important factors in groundnut production. The coefficient of labour was significant at $1 \%$ with an elasticity coefficient of 0.126 which indicated that a $1 \%$ increase in man-days of labour increased groundnut output by $12.6 \%$. This result is similar to that obtained by[17] who observed that labour significantly influenced groundnut output in Benue State, Nigeria. Agrochemical is another significant input in groundnut production with an elasticity coefficient of 0.166 which was statistically significant at $1 \%$ probability level. This implies that a $1 \%$ increase in the use of Agrochemicals would increase output by $16.6 \%$. In their study on groundnut production, [17] and[19]found that quantity of Agrochemicals applied is directly related to groundnut output.

As one of the factor inputs in groundnut production, seed was positive and significant with an elasticity coefficient of 0.430 implying that a $5 \%$ increase in the quantity of seed would increase output by $43 \%$. This result agrees with the findings of [20] who found that increase in seed input can increase agricultural productivity. The elasticity coefficient of farming experience was positive (0.049) and statistically significant at $1 \%$ probability level possibly depicting the impact of experience on groundnut production. This means that experience farmers were likely to achieve higher yields than the inexperience ones which could result in higher 
efficiency and net farm income as well. The result conformed to the findings of [21] who stated that experience is a significant determinant of output in agricultural production. However, the coefficients of fertilizer and extension factors were positive and in agreement with the expected sign whereas the statistical insignificance implies that the factor inputs does not determine output in groundnut production as also indicated by [13].

Table.2: Regression Results of the Various Specified Functional Forms

\begin{tabular}{|c|c|c|c|c|c|c|c|c|c|c|c|}
\hline \multirow[b]{2}{*}{ Functions } & \multirow[b]{2}{*}{ Constant } & \multirow[b]{2}{*}{$\mathrm{X}_{1}$} & \multicolumn{6}{|c|}{ Coefficient of Independent Variables } & \multirow[b]{2}{*}{$\mathrm{R}^{2}$} & \multirow[b]{2}{*}{$\mathrm{R}^{-2}$} & \multirow[b]{2}{*}{ F-value } \\
\hline & & & $\mathrm{X}_{2}$ & $\mathrm{X}_{3}$ & $\mathrm{X}_{4}$ & $\mathrm{X}_{5}$ & $\mathrm{X}_{6}$ & $\mathrm{X}_{7}$ & & & \\
\hline Linear & $\begin{array}{c}1295.541 \\
(8.933)\end{array}$ & $\begin{array}{c}7.127 \\
(1.698)^{*}\end{array}$ & $\begin{array}{c}2.702 \\
(3.775)^{* *}\end{array}$ & $\begin{array}{c}23.582 \\
(2.684)^{* * *}\end{array}$ & $\begin{array}{c}1.263 \\
(1.697)^{*}\end{array}$ & $\begin{array}{c}-103.942 \\
(-\end{array}$ & $\begin{array}{c}2.892 \\
(0.483)\end{array}$ & $\begin{array}{l}48.291 \\
(0.724)\end{array}$ & 59.2 & 48.3 & $9.455 * * *$ \\
\hline \multirow[t]{2}{*}{ Log-linear } & $\begin{array}{c}7.123 \\
(66.175)^{* *}\end{array}$ & $\begin{array}{c}0.006 \\
(1.855)^{*}\end{array}$ & $\begin{array}{c}* \\
0.002 \\
(3.632)^{* *}\end{array}$ & $\begin{array}{c}0.017 \\
(2.583)^{* *}\end{array}$ & $\begin{array}{c}0.001 \\
(1.533)\end{array}$ & $\begin{array}{c}3.783) * * * \\
-0.079 \\
(-\end{array}$ & $\begin{array}{c}0.003 \\
(0.649)\end{array}$ & $\begin{array}{c}0.044 \\
(0.891)\end{array}$ & 50.3 & 47.9 & $9.367 * * *$ \\
\hline & $*$ & & $*$ & & & $3.871)^{* * *}$ & & & & & \\
\hline \multirow[t]{2}{*}{ Linear-log } & -2.863 & 59.875 & 224.271 & 92.188 & 180.217 & 409.345 & 34.200 & 39.110 & 61.4 & 58.7 & $\begin{array}{c}10.982 * * \\
*\end{array}$ \\
\hline & $(-0.009)$ & $(1.791)^{*}$ & $\begin{array}{c}(3.957)^{* *} \\
*\end{array}$ & $(1.574)$ & $\begin{array}{c}(3.027)^{* *} \\
*\end{array}$ & $\begin{array}{c}(4.123)^{* *} \\
*\end{array}$ & $(0.613)$ & $(0.608)$ & & & \\
\hline \multirow[t]{2}{*}{ Double-log } & 2.170 & 0.049 & 0.166 & 0.059 & 0.126 & 0.298 & 0.430 & 0.038 & 74.8 & 71.4 & $\begin{array}{c}10.746 * * \\
*\end{array}$ \\
\hline & $(0.348)$ & $\begin{array}{c}(1.988)^{*} \\
*\end{array}$ & $\begin{array}{c}(3.929) * * \\
*\end{array}$ & (1.359) & $\begin{array}{c}(2.854)^{* *} \\
*\end{array}$ & $\begin{array}{c}(4.038)^{* *} \\
*\end{array}$ & $\begin{array}{c}(3.040)^{*} \\
*\end{array}$ & $(0.790)$ & & & \\
\hline
\end{tabular}

Source: Field Survey, 2017

Note: $* * *, * *$ and $*$ represents $1 \%, 5 \%$ and $10 \%$ significant levels

Figures in parenthesis are t-values

\subsection{Efficiency of resource use analysis}

The Marginal Value Product (MVP) of seeds, labour and farm size were computed and compared to their unit prices in order to determine the degree of efficiency in their use in respect to groundnut production. The results as presented in Table 3shows that the ratios of seeds, labour and
Agrochemicals are greater than unity, indicating that the inputs were under-utilized hence increasing quantity of the inputs use will enhance output and profit level. However, this result is in agreement with the findings of [7], [13] and[17] who observed that resources were inefficiently utilized in groundnut production.

Table.3: Estimated Resource-Use Efficiency in Groundnut Production

\begin{tabular}{lccc}
\hline Variable inputs & MVP & MFC & $\frac{M V P}{M F C}$ \\
& & & 1.19 \\
\hline Seeds & 909.76 & 763.55 & 1.92 \\
Labour & 453 & 235.83 & 3.71 \\
Agrochemicals & 756.56 & 203.74 & \\
\hline
\end{tabular}

Source: Field Survey, 2017

\section{CONCLUSION}

Groundnut production in the study area has been found to be a profitable enterprise as farmers on the average, realized a net income of $\$ 94,540.64$ with a gross margin of $\$ 97,477.80$ at an average selling price of $\$ 280 / \mathrm{kg}$. The regression analysis results revealed that Cobb-Douglas function gave the best fit based on economic, econometric and statistical criteria. The elasticity coefficients of all explanatory variables bore positive signs and hence are in accordance with the apriori expectation. Factor inputs such as agrochemicals, years of farming experience, labour, seeds quantity and land hectares under cultivation 
significantly affects groundnut output at $1 \%$ and $5 \%$ levels of probability. Comparison of the ratio of the MVP to MFC shows that farmer' under-utilized seeds, labour and agrochemicals inputs throughout the cropping season. Thus, increasing quantity of the inputs use will improve production outputand net income level of the farmers. The study recommends that, government should provide funds that could be used to establish research centers for the development of resistant and improved groundnut seed varieties at subsidize rate for use by the farmers. This can aid in minimizing losses arising from prolonged drought and pests as well as shortened the production period of the crop. Farmers' cooperative unions should promote and encourage farm mechanization by developing and distributing simple machines that could impede labour shortage. This can entice prospective youths in to groundnut production and lead to higher productivity and efficiency. Policies aimed at assigning more production inputs to the farmers would enhance output and profitability of the crop in the study area and the country at large.

\section{REFERENCES}

[1] Annual Report of International Crop Research Institute for the Semi-Arid Tropics (2015). A Farmer's Guide to Profitable Groundnut Production in Nigeria. Available at www.icrisat.org.

[2] FAOSTAT. (2016). A database of the Food and Agriculture Organisation of the United Nations (FAO).Retrieved February, 2015 from http://faostat.fao.org.

[3] Taru, V. B., Kyagya, I. Z andMshelia, S. I. (2010). Profitability of groundnut production inMichika local government area ofAdamawa State.Nigerian Journal of Agricultural Science, 1:25-29.

[4] Ndjeunga, J. and Ibro, A. (2010). Groundnut trends and prospects in west and central africa. Technical report, International Crops Research Institute for the Semi-Arid Tropics (ICRISAT).Unpublished Paper.

[5] Abdullahi, S.,Abdulwahab, K. and Abubakar, G. S. (2017). Gross Margin Analysis of Modern Groundnut OilExtraction in Gombe Metropolis Gombe State, Nigeria.World Journal of Agricultural Research,5(2): 58-63.

[6] Audu, S. I., Girei., A. A., Onuk, E. G. and Onyenye, P. O. (2017). Productivity and Profitability of GroundnutProduction (Arachis hypogea L.) in Lafia Local Government Area, Nasarawa State, Nigeria. Asian Research Journal of Agriculture, 4(3): 1-11.
[7] Taphe, B. G., Agbo, F. U. and Okorji, E. C. (2015). Resource Productivity and Technical Efficiency of Small ScaleGroundnut Farmers in Taraba State, Nigeria.Journal of Biology, Agriculture and Healthcare, 5(17): 25-36.

[8] Girei, A. A., Dauna, Y. and Dire, B. (2013).An economic analysis of groundnut (Arachis hypogea)production in Hong Local Government Area of Adamawa State, Nigeria.Journal of Agricultural and Crop Research, 1(6): 84-89.

[9] Madaki, M.J.,Bose, A.A., Abba, Y. I. and Mohammed, J. (2016). Profitabilty of Groundnut Production in Charanchi Local Government Area of Katsina State, Nigeria.International Journal of Information Research and Review,03(03): 2006-2009.

[10] Adinya, I. B. (2009). Analysis of Costs-Returns Profitability in Groundnut Marketing inBekwarra Local Government Area Cross River State, Nigeria.The Journal of Animal \& Plant Sciences, 19(4): 212-216.

[11] Worldometers (2017). Elaboration of data by United Nations, Department of Economic and Social Affairs, Population Division. World Population Prospects: The 2015 Revision available at www.Worldometers.info.

[12] Adebayo, A. A. (1999). Climate II Rainfall in Adebayo, A.A. and Tukur, A.L. (eds.) Adamawa State in Maps.Paracelate Publishers, Yola, Nigeria.

[13] Taru, Y.B., Kyagya, I.Z., Mshelia S.I. and Adebayo,E.F. (2008).Economic Efficiency of Resources use in Groundnut Production in Adamawa state of Nigeria. Whole journal ofA gricultural Science, 4 (s): $896-900$.

[14] Ahmed, M. A. and Egwuma, H. (2015). Assessing Economic Benefits of Cattle Fattening in Sardauna Local Government Area ofTaraba State, Nigeria. International Journal of Innovative Research and Development, 4(13): 353-358.

[15] Olukosi, J.O. and Erhabor, P. O. (2005). Agricultural Farm Management;Principles and Applicaation.Agritab Publications, Zaria, Nigeria.

[16] Nwanosike, M. R. O. (2011). Economic Analysis of Groundnut Enterprise in Rafi Local Government Area of Niger State, Nigeria.International Research Journal of Applied and Basic Sciences, 2(4): 155-162.

[17] Ani, D. P., Umeh, J. C. and Weye, E. A. (2013). Profitability and Economic Efficiency of Groundnut Production in Benue State, Nigeria.African Journal of Food, Agriculture, Nutrition and Development, 13(4): 8091-8105. 
[18] Doll, J. P. and Orazem, F. (1984). Production Economics, Theory with Applications. Columbus, Ohio, Grid Publishing, Inc.

[19] Taphee, G. B. and Jongur, A. A. U. (2014).Productivity and Efficiency of Groundnut Farming in Northern Taraba State, Nigeria. Journal of Agriculture and Sustainability, 5(1): 45-56.

[20] Tashikalma, A.K. (2011). Comparative Economic Analysis of some Rain Fed and IrrigatedFood Crops in Adamawa State, Nigeria. Unpublished Doctoral thesis, Abubakar Tafawa Balewa University Bauchi, Nigeria.

[21] Esiobu, N. S., Onubuogu, G. C. and Okoli, V. B. N. (2014). Determinants of Income from Poultry Egg Production in Imo State, Nigeria: An Econometric Model Approach. Global Advanced Research Journal of Agricultural Science, 3(7): 186-199. 